\title{
GENDER EQUITY IN SECONDARY SCHOOLS OF WEST BENGAL: A CRITICAL STUDY
}

\author{
Marak $\mathrm{R}^{1 *}$ and Sutradhar $\mathrm{P}^{2}$ \\ ${ }^{1}$ Vasanta College for Women, Rajghat, Varanasi, UP, India \\ ${ }^{2}$ North-Eastern Hill University, Shillong, Meghalaya, India
}

\begin{abstract}
Independence brought the dream of an egalitarian, just, democratic society in which both men and women would have a voice and play an important role as agencies of social change, but the reality that gradually dawned was different (NCERT, 2013). While educational policies emphasize equity in universal access to education and increasing the participation of gender in the education process, the literacy rate depicts something different. Achieving gender equity in and through has been a long-standing goal of the education policy in India (GOI, NPE, 1986). Despite significant improvement in the enrolment of girls, girls from disadvantaged communities continue to form the bulk of out-of-school children. Retention and participation of girl student is still an issue. So, there is a need to understand the forces (both push and pull) that shape female access to education, especially in the context of the recent rapid structural transformation of Indian society. In this pursuit, the present paper will reflect the trends of literacy rate and enrolment in Secondary schools of West Bengal from a gender perspective. And it will explore important factors that affect gender equity in Secondary schools of West Bengal. The study will be based on secondary data which will accord data available from different sources like Census, NSSO, U-DISE, articles, books, MHRD reports on school education, newspaper articles, published and unpublished research work etc. This study will scoop out the rough patches of existing educational practices and their space for gender equity.
\end{abstract}

Keywords: access, gender equity, secondary schools

\section{Introduction}

Commitments to gender equality in education have always been a major concern for progressive education policy in India. But still, problems of gender disparity and discrimination is the most prominent issue in India's pursuit for achieving education for all: a legacy of non-productive practices that lead to ineffective learning and increases the dropout rate and repetition. To overcome the problems faced by girls, several measures have been initiated across the country but what impact have these made as reflected in the available statistics remains a huge concern. India accounts for $25.96 \%$ of the world's total illiterate population and around $64.62 \%$ of these illiterates are women. As per 2011 Census data, women constitute $48.57 \%$ of the total population in India, but around $34.54 \%$ of women are still found to be illiterate.

The National Policy on Education, 1986 put specific emphasis on women's education. The chapter titled 'Education for Women's Equality' states: 'Education will be used as an agent of basic change in the status of women. In order to neutralise the accumulated distortions of the past, there will be a wellconceived edge in favour of women. The national education system will play a positive, interventionist role in the empowerment of women. It will foster the development of new values through redesigned curricula, textbooks, the training and orientation of teachers, decision-makers and administrators, and 
the active involvement of educational institutions. This will be an act of faith and social engineering... The removal of women's illiteracy and obstacles inhibiting their access to, and retention in, elementary education will receive overriding priority through the provision of special support services, setting of time targets, and effective monitoring......"(NPE, 1986) ${ }^{l}$.

Besides the NPE 1986, India is also a signatory to several international treaties that reinforce this commitment, such as The Dakar Framework for Action 2000, and the United Nations Millennium Development Goals 2000, the Programme of Action 1992, CEDAW ${ }^{2}$ 1993, The Beijing declaration 1995, and the World Conference on Education for All. Samagra Shiksha ${ }^{3}$ also emphasized bridging the gender and social gap in school education $\left(\mathrm{MHRD}^{4}, 2018\right)$. However, in spite of such policy initiative data shows a widening gender gap concerning attendance and drop out. The literacy gap and the lack of participation of girls in education remains a worrisome aspect for the nation even today, especially in the context of girls from marginalised groups and rural areas. In the majority of the Indian households, preference is given for the wellbeing and educational needs of boys in contrast to girls because of the strong preference towards patriarchal society.

In spite of impressive gains in the participation of children in schooling, a large number of girls still face difficulties in entering school and continuing their studies. The situation is quite adverse in the states like Rajasthan, Uttar Pradesh, Madhya Pradesh, Bihar and West Bengal, where more girls continue to remain out of school than boys and more likely these disparities have increased steadily at higher levels of education. Hence, standing in this threshold, this paper goes to understand the accessibility in terms of literacy rate and enrolment of girls and boys, determining factors of enrolment and how those factors are influenced by pre-defined gender notion. It also tries to understand forces (both push and pull) that shape female access to secondary education in West Bengal, especially in the context of the recent rapid structural transformation of Indian society and an endeavor to identify new spaces and language to promote greater gender equality.

\section{The Rationale of the Study}

Secondary education renders immense social and economic benefits but often lack to retain major concern in our education system. Undoubtedly our country has witnessed a remarkable achievement in the sector of primary education but the same doesn't stand for secondary education and higher secondary education. Secondary education plays a pivotal role as it prepares the workforce for the labour market and creates opportunities for students to acquire higher education. But researches show that secondary education has often been neglected not only at the policy level but also in research and analysis. At present in West Bengal impressive progression has also been made at the primary as well as in the secondary level of education. According to the 2011 census, the West Bengal literacy rate $(77.08 \%)$ is higher than the national literacy rate $(74.04 \%)$. West Bengal has held the $20^{\text {th }}$ position in literacy rate

\footnotetext{
${ }^{1}$ Part IV Education for Women's Equality, cited in National Policy on Education,1986, pp.6

${ }^{2}$ Convention on the Elimination of All Forms of Discrimination against Women, adopted in 1979 by the UN General Assembly

${ }^{3}$ Centrally Sponsored Integrated Scheme for School Education, MHRD, 2018

${ }^{4}$ Ministry of Human Resource Development
} 
among all states and union territories. In West Bengal 92.82 percentages of habitations have secondary stage schooling facility up to a distance of $5 \mathrm{~km}$. The number of secondary schools increases from 9773 in 2012-2013 to 10359 in 2016-2017. The teacher-pupil ratio also declined from 1:45 in 2012-2013 to 1:19 in 2016-2017.

But despite all of these significant achievements, achieving the goal of universalization of secondary education and RMSA ${ }^{5}$ remains far out of sight. If we look at the percentage distribution of children and adolescents of different age groups across different educational levels, it is disturbing to note that only 12.3 percent of boys and 11.7 percent of girls in the 15 years and above age group have ventured beyond middle school in the rural part of West Bengal. Similarly, only 14.5 percent of boys and 14.9 percent of girls are studying in secondary school and above in the urban part of West Bengal. The gender gap in the literacy rate of the rural \& urban part of West Bengal is 9.4 percent and 6.7 percent respectively. An overwhelming number of children barely complete primary school, with many of them dropping out before they reach (NSS 75th Round, 2017) ${ }^{6}$.

Standing on the brink between adulthood and childhood - their predicament has been largely ignored. Adolescent girls are vulnerable. A very large number enter into matrimony and become young mothers and take on household responsibilities before they have the opportunity to realise their full potential. In the age group, 3 to 35 years, among the never enrolled persons, $11.7 \%$ females and $1.5 \%$ males were never enrolled as they were engaged in economic activities. As per NSS $75^{\text {th }}$ Round (July 2017- June 2018), for persons in the age group, 3 - 35 years ever enrolled, $30.2 \%$ of females are currently not attending education due to engagement in domestic activities. The percentage of women representation in the Central Council of Ministers has decreased from $17.8 \%$ in 2015 to $10.5 \%$ in 2019. Census data for the state hides wide intra-state regional differences and variations across communities. The situation is more critical for the marginalized section who are not merely deprived of the basic necessity of life but also have to face severe hardship to earn their livelihood. Hence preferred their girl child either to discontinue their studies or to engage in household activities. According to NCAER / HDI survey, it is evident that "even in relatively advanced areas like Andhra Pradesh and Tamil Nadu, while enrolment rates are high, most of the discontinuation happens in the 12-14 age group - especially for girls" (Ramachandran 2003) ${ }^{7}$. From the above, it is apparent that there is an enormous lack of researches concerning Gender Equity in the Secondary Schools of West Bengal. This denotes a knowledge gap in context, which is expected to be fulfilled by the present researcher.

\footnotetext{
${ }^{5}$ Rashtriya Madhyamik Shiksha Abhiyan, 2009, a flagship scheme of Government of India, to enhance access to secondary education and improve its quality

${ }^{6}$ The survey of Household Social Consumption on Education in India conducted by National Stistical Office(NSO), cited in Government of India (July 2017-June 2018)

${ }^{7}$ Paper commissioned for the EFA Global Monitoring Report 2003/4, The Leap to Equality, pp.6
} 


\section{Objectives}

From the above observation, the researcher will discuss the following objectives.

1. To study the trends of literacy rate in secondary schools of West Bengal from a gender perspective.

2. To study the trends of enrolment in secondary schools of West Bengal from a gender perspective.

3. To explore important factors that affect gender equity in secondary schools of West Bengal.

\section{Methodology}

The present paper entitled "Gender Equity in Secondary Schools of West Bengal: A Critical Study" is descriptive in nature. Keeping in view the limitation of time, availability of resources and energy, the researcher conducted the study based on secondary data. In this paper data from Census, NSSO, UDISE, MHRD reports on school education, various policies \& commissions have been extensively used. The researcher also goes through some national and international journals related to the issues of access, equity, and quality in secondary education Thus, the researcher utilized all resources available and carried out an exhaustive study for the present research paper.

\section{Analysis and Interpretation}

\section{Trends of Literacy rate in secondary schools of West Bengal}

Table 1: District wise trends of literacy rate of secondary schools of West Bengal

\begin{tabular}{|l|l|l|l|l|l|l|l|l|l|}
\hline \multirow{2}{*}{$\begin{array}{l}\text { Sl. } \\
\text { No. }\end{array}$} & \multirow{2}{*}{ District/State } & \multicolumn{1}{l}{1981} & \multicolumn{1}{l}{1991} & \multicolumn{2}{l}{2001} & \multicolumn{3}{l|}{2011} \\
\cline { 2 - 10 } & & $\mathrm{M}$ & $\mathrm{F}$ & $\mathrm{M}$ & $\mathrm{F}$ & $\mathrm{M}$ & $\mathrm{F}$ & $\mathrm{M}$ & $\mathrm{F}$ \\
\hline 1. & Darjeeling & 51.6 & 32.4 & 67.1 & 47.8 & 81.3 & 63.9 & 85.6 & 73.3 \\
\hline 2. & Jalpaiguri & 38.5 & 20.5 & 56 & 33.2 & 73.6 & 52.9 & 80 & 66.2 \\
\hline 3. & Cooch Behar & 40 & 19.3 & 57.4 & 33.3 & 76.8 & 57 & 80.7 & 68.5 \\
\hline 4. & Uttar Dinajpur & 36.1 & 17.1 & 45.2 & 22.9 & 59.3 & 37.2 & 66.5 & 52.2 \\
\hline 5. & Dakshin Dinajpur & & & 56.8 & 35.3 & 73.3 & 55.12 & 78.4 & 67 \\
\hline 6. & Malda & 31.5 & 14.2 & 45.6 & 24.9 & 59.24 & 41.7 & 66.2 & 57 \\
\hline 7. & Murshidabad & 32.4 & 17.3 & 46.4 & 29.6 & 61.4 & 48.3 & 70 & 63 \\
\hline 8. & Birbhum & 43 & 24 & 56.3 & 37.2 & 71.6 & 52.21 & 77 & 64.1 \\
\hline 9. & Bardhaman & 50.9 & 33.8 & 71.1 & 51.5 & 79.3 & 62 & 82.4 & 69.6 \\
\hline 10. & Nadia & 43.7 & 29.4 & 60.1 & 44.4 & 72.7 & 60 & 78.8 & 71 \\
\hline 11. & North 24 Pargana & 55.4 & 35.4 & 60.1 & 58 & 84.4 & 72.13 & 87.6 & 80.3 \\
\hline 12. & South 24 Pargana & & & 68.5 & 40.6 & 79.9 & 59.7 & 83.4 & 71.4 \\
\hline 13. & Hoogly & 57.9 & 38.8 & 75.8 & 56.9 & 83 & 67.7 & 87 & 76 \\
\hline 14. & Bankura & 49.4 & 23.1 & 66.8 & 36.6 & 77.2 & 49.8 & 80 & 60 \\
\hline
\end{tabular}




\begin{tabular}{|l|l|l|l|l|l|l|l|l|l|}
\hline 15. & Purulia & 45.6 & 13.3 & 62.2 & 23.2 & 74.2 & 37.2 & 77.9 & 50.5 \\
\hline 16. & Medinapur & 55.3 & 29.7 & 81.3 & 56.6 & 85.9 & 59.7 & 88.8 & 76 \\
\hline 17. & Howrah & 60.7 & 40.8 & 76.1 & 57.8 & 83.7 & 71 & 87 & 79.4 \\
\hline 18. & Kolkata & 73.2 & 63.1 & 81.9 & 72.1 & 84 & 78 & 88.3 & 84 \\
\hline & WEST BENGAL & 50.5 & 30.3 & 67.8 & 46.6 & 77 & 59.7 & 81.7 & 70.5 \\
\hline
\end{tabular}

Source ${ }^{8}$ : Census of West Bengal, 2011 \& National Commission for Women, 2004.

From the above table 1, it can be interpreted that in recent years, West Bengal has reportedly shown considerable improvement in literacy rate for both males as well as for females. Though the female literacy rate has improved by $16.3 \%$ from 1981 - 1991, while the increase was $10.8 \%$ during the next decade. The gender gap in literacy has also narrowed with the due passage of time, although there was still a gap of 11.2 percentage points between the genders according to the 2011 Census, in comparison to a 20.2 percentage point gap 30 years earlier.

Further, while analysing District-wise literacy figures as given in Table 1, It can be seen that in 1981, female literacy rates were usually lower than 30 percent in the districts of West Bengal (Kolkata and Howrah being two notable exceptions); In 2011 about half the districts had reached or crossed the 60 percent mark. However, the female literacy rate continued to be lower than 55 percent in Uttar Dinajpur and Purulia, both with a substantial component of the tribal population. It is striking to note that these districts show a pervasive gender gap of $14 \%$ and $27.4 \%$ respectively accompanied by Bankura district which also reflects a huge gender gap of $20 \%$ as compared to all other districts of the state. Hence it could be inferred that a comprehensive increase in the literacy rate of the state does not depict true disparities that exist across the district.

\section{Trends of Enrolment in secondary schools of West Bengal}

The best indicator to measure access to secondary education is enrolment, which measures the total number of enrolments of a specific academic year in secondary education. The enrolment status of various social groups and religious minorities for both boys and girls during $2010-11$ to 2016 - 17 at secondary schools of West Bengal is presented in Table 2. To understand the access of secondary education, the researcher analysed the 2010-11 to 2016-17 number of enrolment data of U-DISE of West Bengal.

Table 2: Details of Enrolment of secondary school students of West Bengal

\begin{tabular}{|l|l|l|l|l|l|l|}
\hline $\begin{array}{l}\text { Secondary } \\
\text { Enrolment } \\
\text { (year) }\end{array}$ & $2010-11$ & $2012-13$ & $2013-14$ & $2014-15$ & $2015-16$ & $2016-17$ \\
\hline $\begin{array}{l}\text { Total (in } \\
\text { numbers) }\end{array}$ & 2206419 & 2414783 & 2534192 & 2630890 & 2759187 & 2594254 \\
\hline$\%$ of Girls & 51.21 & 52.7 & 53.1 & 53.7 & 54.1 & 54.8 \\
\hline$\%$ of Boys & 48.79 & 47.3 & 46.9 & 46.3 & 45.9 & 45.2 \\
\hline
\end{tabular}

\footnotetext{
${ }^{8}$ Note: Figures for North 24 Parganas stand for undivided 24 Parganas districts and figures for Uttar Dinajpur stand for undivided Dakshin Dinajpur
} 


\begin{tabular}{|l|l|l|l|l|l|l|}
\hline $\begin{array}{l}\text { \% of SC } \\
\text { Boys }\end{array}$ & 51 & 49.58 & 49.18 & 48.68 & 48.16 & 46.92 \\
\hline $\begin{array}{l}\text { \% of SC } \\
\text { Girls }\end{array}$ & 49 & 50.42 & 50.82 & 51.32 & 51.84 & 53.08 \\
\hline $\begin{array}{l}\text { \% of ST } \\
\text { Boys }\end{array}$ & 53.7 & 50.40 & 49.14 & 49.21 & 47.99 & 47.06 \\
\hline $\begin{array}{l}\text { \% of ST } \\
\text { Girls }\end{array}$ & 46.3 & 49.60 & 50.86 & 50.79 & 52.11 & 52.94 \\
\hline $\begin{array}{l}\text { \% of } \\
\text { Muslim } \\
\text { Girls }\end{array}$ & - & 58.7 & 59.79 & 60.32 & 61.23 & 62.26 \\
\hline
\end{tabular}

Source: U-DISE: State Report Cards of 2010-11, 2012-13, 2013-14, 2014-15, 2015-16 \& 2016-17.

From the above table, it is quite evident that there has been a considerable increase in the participation of girls in school because of an increase in enrolments. However, substantial differences emerge when figures are disaggregated for different social categories. While the enrolment trend is increasing for girls among various social groups over the years but the trend is somewhat reverse for boys showing a decline in enrolment trend. In $2010-11,49 \%$ of SC girls were enrolled in school as compared to 51\% SC boys and $46.3 \%$ of ST girls were enrolled as compared to $53.7 \%$ showing a gap of $2 \%$ and $7.4 \%$ respectively. But the figure is strikingly different during the year $2016-17$ with the increase in enrolment percentage of SC and ST girls to 53.08\% and 52.94\% while the scenario is quite reverse for the boys showing a reduction in the enrolment percentage to $46.92 \%$ and $47.06 \%$ respectively.

But the question arises do merely an increase in enrolment of girls entail a reduction in inequalities in access and participation beyond entry-level, an increase in retention and attendance level and ensure effective learning outcome?

Table 3: Percentage distribution of students of West Bengal by enrolment Status

\begin{tabular}{|c|c|c|c|c|c|c|}
\hline \multirow[t]{3}{*}{ Area } & \multicolumn{6}{|c|}{ Enrolment Status 2017-18 } \\
\hline & \multirow[t]{2}{*}{ Gender } & \multicolumn{3}{|c|}{ Currently not attending } & \multirow{2}{*}{$\begin{array}{l}\text { Currently } \\
\text { attending }\end{array}$} & \multirow[t]{2}{*}{ Overal } \\
\hline & & $\begin{array}{l}\text { Not } \\
\text { enrolled }\end{array}$ & $\begin{array}{l}\text { Enrolled in } \\
\text { previous } \\
\text { year but not } \\
\text { attending } \\
\text { currently }\end{array}$ & $\begin{array}{l}\text { Enrolled in } \\
\text { present year } \\
\text { but not } \\
\text { attending } \\
\text { currently }\end{array}$ & & \\
\hline \multirow[t]{2}{*}{ RURAL } & MALE & 11.5 & 46.1 & 0.3 & 42 & 100 \\
\hline & FEMALE & 13.1 & 44.4 & 0.2 & 42.3 & 100 \\
\hline \multirow{2}{*}{ URBAN } & MALE & 6.5 & 49.2 & 0.5 & 43.8 & 100 \\
\hline & FEMALE & 8.2 & 48.1 & 0.8 & 42.9 & 100 \\
\hline
\end{tabular}

Source: NSSO Report (2017-2018).

\footnotetext{
${ }^{9}$ Unified District Information on School Education, initiated in 2012-13 by Department of School Education, MHRD, Government of India
} 
From the above table, it is observed that though enrolled, a total of $57.7 \%$ of female students are currently not attending secondary school in the rural part of West Bengal and the number is not quite impressive for the urban part of West Bengal with $57.1 \%$ female students currently not attending secondary schools. And the number is higher than currently attending.

\section{Factors that affect gender equity in secondary schools of West Bengal}

Availability of School

Unprecedented expansions of schools in the last two decades cannot be contested. What has to be examined from the point of view of inequality in the system is the nature of these schools, their location and the population groups that they serve. Improvements in educational access in West Bengal were quite spectacular with $32.6 \%$ and $69.9 \%$ schools within a $1 \mathrm{KM}$ radius and $6.7 \%$ and $0.5 \%$ schools within a $5 \mathrm{KM}$ radius in rural and urban West Bengal respectively. Intriguingly, the enormous expansion of schools and improved supply and wider distribution of school infrastructure initiated through RMSA however, fail to depict reduction in inequalities in access and participation beyond the entry-level, marginal reduction of inequalities in overall attainment levels and inequalities in learning outcome.

Table 4: Percentage of Nearest School having Secondary level Classes

\begin{tabular}{|l|l|l|l|l|l|l|}
\hline \multirow{2}{*}{ Area } & \multicolumn{6}{|l|}{ \% of Nearest School having secondary level Classes } \\
\cline { 2 - 7 } & $\begin{array}{l}\text { Less than 1 } \\
\text { Km }\end{array}$ & $\begin{array}{l}1 \mathrm{Km} \text { or } \\
\text { Greater } \\
\text { than but } \\
\text { less than 2 } \\
\text { Km }\end{array}$ & $\begin{array}{l}\text { 2 Km or } \\
\text { Greater } \\
\text { than but } \\
\text { less than 3 } \\
\text { Km }\end{array}$ & $\begin{array}{l}\text { 3 Km or } \\
\text { Greater } \\
\text { than but } \\
\text { less than } \\
\text { Km }\end{array}$ & $\begin{array}{l}\text { 4 Km or } \\
\text { Greater } \\
\text { than but } \\
\text { less than 5 } \\
\text { Km }\end{array}$ & Overall \\
\hline $\begin{array}{l}\text { WEST } \\
\text { BENGAL } \\
\text { (RURAL) }\end{array}$ & 32.6 & 33.2 & 17.5 & 10.1 & 6.7 & 100 \\
\hline $\begin{array}{l}\text { INDIA } \\
\text { (RURAL) }\end{array}$ & 37.5 & 23.9 & 16.3 & 8.9 & 13.5 & 100 \\
\hline $\begin{array}{l}\text { WEST } \\
\text { BENGAL } \\
\text { (URBAN) }\end{array}$ & 69.9 & 21.9 & 5 & 2.7 & 0.5 & 100 \\
\hline $\begin{array}{l}\text { INDIA } \\
\text { (URBAN) }\end{array}$ & 69.9 & 19.5 & 6.6 & 2.6 & 1.3 & 100 \\
\hline
\end{tabular}

Source: NSSO Report (2017-2018).

With reference to Table 4, it is observed that inter-regional disparities get accentuated when we examine access to secondary schooling concerning rural-urban variations through a proximate location. While $69.9 \%$ of schools are within a $1 \mathrm{KM}$ radius in the urban region, the percentage falls drastically to $32.6 \%$ in the rural region showing a gap of $37.3 \%$. There were $6.7 \%$ nearest schools having secondary level classes within a $5 \mathrm{KM}$ radius in rural West Bengal and $0.5 \%$ nearest schools having secondary level classes within a $5 \mathrm{KM}$ radius in urban West Bengal. 
Therefore the availability of schools within walking distances from habitations is an important factor in increasing girls' enrolment. In NFHS-II ${ }^{10}, 3.4 \%$ of urban and $5.2 \%$ of rural females were not enrolled in school because of distance. The survey also reported that due to lack of access to schools about $7.5 \%$ of rural girls and $1.2 \%$ of urban girls were pushed out. The score is lower in the case of boys: $1.4 \%$ for rural and $0.3 \%$ for urban boys. This suggests that the non-availability of schools still affects girls' education in rural areas.

\section{Dropping Out}

The dropout rate in comparison to enrolment is an important factor of quality measure of a specific level of education. In this section, the researcher compares the class IX and class $\mathrm{X}$ dropout rate in comparison to the enrolment of their level.

Table 5: Dropout rate of class X and Class IX during 2013-14 to 2016-17

\begin{tabular}{|c|c|c|c|c|}
\hline \multirow[t]{2}{*}{ Year } & \multicolumn{2}{|l|}{ Class X } & \multicolumn{2}{|l|}{ Class IX } \\
\hline & Total Enrolment & Dropout Rate & Total Enrolment & Dropout Rate \\
\hline 2013-14 & 1065150 & 22.77 & 1171353 & 12.93 \\
\hline $2014-15$ & 1125441 & 20.68 & 1505449 & 13.42 \\
\hline $2015-16$ & 1230469 & 22.41 & 1528718 & 14.35 \\
\hline $2016-17$ & 1114974 & 28.25 & 1479280 & 25.87 \\
\hline
\end{tabular}

Source: UDISE: State Report Cards of 2013-14, 2014-15, 2015-16 \& 2016-17.

Above table 5 shows that enrolment as well as dropout rate increases year by year among both the classes. It is quite evident that in 2014-15 and 2015-16 dropout rate is less than the enrolment (in lakh) but the dropout rate significantly increases in the year 2013-14 and last year 2016-17. In both classes, enrolment is increasing in 2013-14 to 2014-15 and 2014-15 to 2015-16 as well as the dropout rate slightly increasing year by year. From 2015-16 to 2016-17 enrolment in both classes has been decreasing but the dropout rate drastically increased. National-level surveys and data also show that 9 out of every 10 girls ever enrolled in school could not complete schooling and only 1 out of every 100 girls enrolled in class reaches Class XII in rural areas and 14 out of every 100 girls enrolled in Class I reach Class XII in urban areas (NCERT, 2006). The high dropout rates have always put a question mark over the capacity of schools to retain their students, the quality of teaching, and ability of teachers and above all efficacy of the system itself.

\section{Reasons for children's non-attendance}

Why do children drop out? Why do the maximum number of girls fail to accomplish the secondary stage? Why are learning outcomes poor? These questions have worried the thinking minds of the nation.

NSSO, 2017 has collected information on reasons for children's non-attendance in school. Although this information is not available separately for different social groups, the data elucidate why some children never attend school and why others do drop out.

10 The second National Family Health Survey, conducted in 1998-99, Government of India 
Table 6: Percentage distribution of secondary level students of West Bengal by major reason for currently not attending

\begin{tabular}{|c|c|c|c|c|c|c|c|c|c|c|c|c|}
\hline \multirow[t]{2}{*}{ Area } & \multirow[t]{2}{*}{$\begin{array}{l}\text { Gende } \\
\mathrm{r}\end{array}$} & \multicolumn{11}{|c|}{$\begin{array}{l}\text { Percentage distribution of ever enrolled persons by major reason for currently not } \\
\text { attending }\end{array}$} \\
\hline & & $\begin{array}{l}\text { Not } \\
\text { interes } \\
\text { ted in } \\
\text { educat } \\
\text { ion }\end{array}$ & $\begin{array}{l}\text { Financi } \\
\text { al } \\
\text { constra } \\
\text { ints }\end{array}$ & $\begin{array}{l}\text { Engag } \\
\text { ed in } \\
\text { domes } \\
\text { tic } \\
\text { activit } \\
\text { ies }\end{array}$ & $\begin{array}{l}\text { Engag } \\
\text { ing in } \\
\text { econo } \\
\text { mic } \\
\text { activiti } \\
\text { es }\end{array}$ & $\begin{array}{l}\text { Scho } \\
\text { ol is } \\
\text { far } \\
\text { awa } \\
y\end{array}$ & $\begin{array}{l}\text { Una } \\
\text { ble } \\
\text { to } \\
\text { cope } \\
\text { up } \\
\text { with } \\
\text { studi } \\
\text { es }\end{array}$ & $\begin{array}{l}\text { Com } \\
\text { plete } \\
\text { d } \\
\text { desir } \\
\text { ed } \\
\text { level } \\
\text { class }\end{array}$ & $\begin{array}{l}\text { Prepar } \\
\text { ation } \\
\text { for } \\
\text { compe } \\
\text { titive } \\
\text { exams }\end{array}$ & $\begin{array}{l}\text { mar } \\
\text { riag } \\
\mathrm{e}\end{array}$ & $\begin{array}{l}\text { oth } \\
\text { ers }\end{array}$ & all \\
\hline \multirow{2}{*}{$\begin{array}{l}\text { RUR } \\
\text { AL }\end{array}$} & MALE & 20.6 & 40.9 & 1.2 & 26.5 & 0 & 5.6 & 1.7 & 0.8 & - & 2.6 & 100 \\
\hline & $\begin{array}{l}\text { FEMA } \\
\text { LE }\end{array}$ & 13 & 34.3 & 16.6 & 1.7 & 1 & 4.8 & 1.4 & 0.3 & $\begin{array}{l}20 . \\
9\end{array}$ & 6 & 100 \\
\hline \multirow{2}{*}{$\begin{array}{l}\text { URB } \\
\text { AN }\end{array}$} & MALE & 13.6 & 36.7 & 0.8 & 30.4 & 0 & 5.1 & 8.6 & 2.3 & - & 2.6 & 100 \\
\hline & $\begin{array}{l}\text { FEMA } \\
\text { LE }\end{array}$ & 11.5 & 28.3 & 13.8 & 3.2 & 0.1 & 4.9 & 11.7 & 1.4 & $\begin{array}{l}20 . \\
4\end{array}$ & 4.7 & 100 \\
\hline
\end{tabular}

Source: NSSO Report (2017-2018).

Table 7: Percentage distribution of secondary level students of West Bengal by major reason for never enrolled

\begin{tabular}{|c|c|c|c|c|c|c|c|c|c|c|c|}
\hline \multirow[t]{2}{*}{ Area } & \multirow{2}{*}{$\begin{array}{l}\text { Gende } \\
\mathrm{r}\end{array}$} & \multicolumn{10}{|c|}{ Percentage distribution of never enrolled persons by major reason for never enrolled } \\
\hline & & $\begin{array}{l}\text { Not } \\
\text { interes } \\
\text { ted in } \\
\text { educat } \\
\text { ion }\end{array}$ & $\begin{array}{l}\text { Financi } \\
\text { al } \\
\text { constra } \\
\text { ints }\end{array}$ & $\begin{array}{l}\text { Engag } \\
\text { ed in } \\
\text { domes } \\
\text { tic } \\
\text { activit } \\
\text { ies }\end{array}$ & $\begin{array}{l}\text { Engag } \\
\text { ing in } \\
\text { econo } \\
\text { mic } \\
\text { activiti } \\
\text { es }\end{array}$ & $\begin{array}{l}\text { Scho } \\
\text { ol is } \\
\text { far } \\
\text { awa } \\
y\end{array}$ & $\begin{array}{l}\text { Timings } \\
\text { of } \\
\text { educati } \\
\text { onal } \\
\text { instituti } \\
\text { on not } \\
\text { suitable }\end{array}$ & $\begin{array}{l}\text { No } \\
\text { traditio } \\
\mathrm{n} \text { in } \\
\text { commu } \\
\text { nity }\end{array}$ & $\begin{array}{l}\text { marria } \\
\text { ge }\end{array}$ & $\begin{array}{l}\text { othe } \\
\text { rs }\end{array}$ & all \\
\hline \multirow[t]{2}{*}{$\begin{array}{l}\text { RUR } \\
\text { AL }\end{array}$} & MALE & 23.1 & 23.1 & 0.2 & 2.2 & 0.7 & 0.1 & 0.6 & - & 50.1 & $\begin{array}{l}10 \\
0\end{array}$ \\
\hline & $\begin{array}{l}\text { FEMA } \\
\text { LE }\end{array}$ & 19.9 & 24.1 & 4.9 & 0.2 & 0.3 & 0.3 & 1.4 & 0.2 & 48.7 & $\begin{array}{l}10 \\
0\end{array}$ \\
\hline \multirow[t]{2}{*}{$\begin{array}{l}\text { URB } \\
\text { AN }\end{array}$} & MALE & 18.5 & 27.2 & 0.9 & 4.6 & 0.5 & 0 & 1.7 & - & 46.6 & $\begin{array}{l}10 \\
0\end{array}$ \\
\hline & $\begin{array}{l}\text { FEMA } \\
\text { LE }\end{array}$ & 13.7 & 25 & 4.4 & 3.5 & 0.5 & 0 & 5.6 & 0.2 & 47 & $\begin{array}{l}10 \\
0\end{array}$ \\
\hline
\end{tabular}

Source: NSSO Report (2017-2018).

From the above tables ( $6 \& 7)$, it is well reflected that the high cost of providing education or financial constraints and disinterest in studies accounted for nearly 50 percent of the boys in both rural and urban areas who never attended school. For girls, along with the cost of education, their usefulness in the 
home and help in household work and marriages were given as major reasons for non-attendance. The major reasons cited for children who dropped out of school were lack of interest, financial constraint, marriages and the necessity for them to work for cash or kind at home or outside.

So, it can be interpreted that even though schooling is free, especially in rural areas, and more specifically for girls, there are some hidden costs. Lack of interest in studies can stem from several reasons, ranging from a disabling study environment in the home, lack of facilities in schools, irregularity of teachers, lack of equity pedagogy, to the low social status of some children and their families within the community leading to harassment in the school.

\section{Gender Stereotyping in Schools}

Gender stereotyping in textbooks and learning materials is also one of the fundamental systemic issues that constrain progress towards gender equality in education. Several types of research argue that men continue to be the main characters in textbooks and to be depicted in higher positions than women, while women's achievements are rarely recognized. To quote Position Paper National Focus Group on Gender Issues in Education, "In my textbooks, I learned that only men are kings and soldiers. Till I read a book in which famous, queens ruled and fought against enemies. In my textbooks I learned that only men are doctors. When I went to the doctor, I saw that she was a woman. In my textbook I learned that only men do farming in my country, until, on a train journey I saw women working in the fields. I have learned that I have a lot to learn by seeing" - (NCERT, 2006).

Further, The POA (1992) noted the issue of the non-availability of Mathematics and science teachers in girls' schools and emphasizes the need to change the situation. However, there rarely exists any monitoring mechanism to ensure actions on these policy directions. In fact, the choice of opting for 'nonwomanly' subjects remains only notional in most of the single-sex girls' schools for want of teachers in non-stereotyped courses (CABE Report, 2005) ${ }^{11}$. The reinforcement of this gender divide can be seen even in the choice of vocational courses (Bandyopadhyay \& Subrahmanian, 2008).

\section{Gender differences in learning achievement}

The examination system is necessarily held to test the learning ability and competency of a student. Students in secondary schools of West Bengal have to have appeared in the grade X exam. These examinations are significant because this certification becomes an instrument for higher education and the selection of professional course. So, the researcher used this exam result as a performance indicator of quality.

Table 8: Achievement of class X students during 2012-13 to 2016-17

\begin{tabular}{|l|l|l|l|l|l|l|l|l|}
\hline \multirow{2}{*}{ Years } & \multicolumn{2}{|l|}{ General } & \multicolumn{2}{l}{ SC } & \multicolumn{2}{l|}{ ST } & \multicolumn{2}{l|}{ OBC } \\
\cline { 2 - 10 } & Boys & Girls & Boys & Girls & Boys & Girls & Boys & Girls \\
\hline $2012-13$ & 89.87 & 82.71 & 82.56 & 74.36 & 76.58 & 64.61 & 86.37 & 74.76 \\
\hline $2013-14$ & 89.86 & 82.47 & 82.55 & 74.06 & 71.93 & 60.26 & 87.59 & 76.78 \\
\hline
\end{tabular}

${ }^{11}$ Report of the CABE Committee on Girls' Education and the Common School System, cited in MHRD, 2005, pp.8 


\begin{tabular}{|l|l|l|l|l|l|l|l|l|}
\hline $2014-15$ & 89.02 & 82.82 & 82.93 & 76.45 & 72.8 & 65.76 & 85.7 & 77.72 \\
\hline $2015-16$ & 89.86 & 84.94 & 79.64 & 75.43 & 74.99 & 67.87 & 85.67 & 76.92 \\
\hline $2016-17$ & 93.3 & 94.21 & 93.31 & 91.3 & 88.95 & 86.31 & 94.14 & 93.75 \\
\hline
\end{tabular}

Source: UDISE: State Report Cards of 2012-13, 2013-14, 2014-15, 2015-16 \& 2016-17.

Table 8 clearly shows the learning outcome of class X students (both male \& female) during $2012-13$ to 2016 - 17 across all social groups. While the number of girls students passing in class $\mathrm{X}$ increases substantially with the year among all social groups. But if compare the general, SC, ST and OBC it is seen that the schedule caste and schedule tribe girl students in class $\mathrm{X}$ have a low pass out rate throughout the year. Among all social group, schedule tribes are most educationally backward. If compare the achievement of both boys and girls it has been observed that boys are consistently performing better than the girls in the exam of class X. Only in the year 2016-17 girls perform better than the boys in the general category.

And several types of research states that learning outcomes of girls across all social groups are also influenced by a range of factors, including quality of educational facilities, teacher attendance, home environment, socio-economic contexts, parental education, family size, attendance, household duties, nutrition, and attendance at pre-school (Kingdon, 1998a; Bashir, 1994; Govinda and Varghese 1993; Roy et al, 1995; World Bank, 1997; Ramachandran 2003a; Reddy 2004b; Govinda and Varghese 1993; Aggarwal, 2000a; Hasan 1995) which narrow down their scope for further higher studies.

\section{Other Challenging issues}

In West Bengal to ensure secondary education, the West Bengal Board of Secondary Education was established under the West Bengal Secondary Education Act, 1963 and which was amended from time to time. However, in terms of access, equity and quality, secondary education cannot be ensured totally. Some issues emerged related to access, equity and quality of secondary education of West Bengal which is discussed below.

1.1. India made a constitutional commitment to provide free and compulsory education to all children up to age 14. So, there are no tuition fees up to class VIII. But when it comes to secondary schools, "Several government-aided schools charge fees above the prescribed limit"( Times of India, 2017). Which is not affordable for the students across various social groups especially the marginalized section. Therefore there is a high dropout rate among the secondary students of West Bengal due to the unbearable tuition fees and other additional costs. They think that it is better to earn bread rather than earn for school fees.

1.2. There are various scholarship schemes of the government and private for the $\mathrm{SC}, \mathrm{ST}$ and $\mathrm{OBC}$ students. But the government never undertakes any initiative to create awareness among the students about those schemes. Thus as a result of which students fail to avail those schemes. Sometimes irregularities in the credit of the scholarship in the respective bank account demotivate the students to actively engage in the teaching-learning process.

1.3. One of the major issues of secondary schools of West Bengal is the lack of ICT labs and internet facility which affects student participation and retention. 
1.4. Since 2009 the school service commission of West Bengal is not conducting any teacher recruitment process. As a result of which there is a dearth of trained teachers in the schools of West Bengal which affects the quality of the teaching-learning process.

1.5. Table 2 shows that the enrolment of girls is higher than the boys in the secondary level. If analysed the repetition in Class IX-X of girls, it is found that the repetition among the girls is higher than the boys. So, enrolment of girls is showing the better condition of girls in terms of equality but repetition talks about the stagnation of girls' education.

\section{Conclusion}

One of the dimensions in educational development is equity particularly in a highly stratified society like West Bengal. The educational expansion and dynamics of development and the delivery mechanism of secondary education in West Bengal are well examined. But does this expansion entail Equity? The Constitution of India guarantees the right to equality to all its citizen but in reality, to what extent this equity prevails is a big question. So, policy initiatives must aim to achieve the target not only in theory concerning enrolment and retention of girls students but also in terms of process and practice ensuring relative achievement and performance at all levels and in all subjects. There needs to be an ardent urge to promote girls' education and support them beyond the elementary level. Incentives offered for promotion of girls' education need to be revisited and the measures taken need to be of such nature, force and magnitude that they can overcome the hurdles confronted by various factors such as low socio-economic background, household responsibilities, engagement in economic activity, low preference to girls' education, early marriage, etc.

Henceforth, the goal of achieving the 'Education for All' should not merely rely on access to educational facilities and enrolment alone; rather it requires an intense emphasis on a meaningful and relevant curriculum, human resource management systems that ensure regularity and accountability, and availability of qualified and professionally trained teachers, equity pedagogy, that would enable enhanced student retention, attainment and achievement. A high number of tough questions need to be asked and research studies are needed to focus on these questions in order to support improvements to gender equity not only in West Bengal but across India.

\section{References}

Aggarwal, J. C. (2010). Landmarks In The History Of Modern India. New Delhi: Vikas Publishing House.

Bandyopadhyay, M., \& Subrahmanian, R. (2008). Gender Equity in Education: AReview of Trends and Factors. New Delhi: Consortium for Research on Educational Access, Transitions and Equity(CREATE).

Bedi, J. S., \& Ramachandran, H. (1994). Human Development Index for Rural Andhra Pradesh. New Delhi: National Council of Applied Economic Research/HDI.

CABE. (2005). Girls' Education and the Common School System. New Delhi: Ministry of Human Resource Development.

Chattoraj, K. K., \& Chand, S. (2015). Literacy Trend of West Bengal and Its Differentials: A District Level Analysis. IOSR Journal Of Humanities And Social Science (IOSR-JHSS), 20(9(III)), 01-19. 
GOI. (1986). National Policy on Education-1986. New Delhi: Ministry of Human Resource Development. Retrieved from http://psscive.ac.in/assets/documents/Policy_1986_eng.pdf

GOI. (1992). National Policy on Education-1986: Programme on Action(1992). New Delhi: Ministry of Human Resource Development. Retrieved from https://www.education.gov.in/sites/upload_files/mhrd/files/upload_document/npe.pdf

GOI. (2011). Census of India 2011. New Delhi: Office of the Registrar General \& Census Commissioner, India, Ministry of Home Affairs. Retrieved from https://censusindia.gov.in/

GOI. (2020). Household Social Consumption on Education in India: NSS $75{ }^{\text {th }}$ Round(July 2017- June 2018). New Delhi: Ministry of Statistics and Programme Implementation(National Statistical Office). Retrieved from http://mospi.nic.in/sites/default/files/publication_reports/Report_585_75th_round_Education_final_15 07_0.pdf

Ministry of Statistics and Programme Implementation. (2019). Women \& Men in India. New Delhi: National Statistical Office(GOI).

Mukherjee, M. (2004). A SITUATIONAL ANALYSIS OF WOMEN AND GIRLS IN WEST BENGAL. New Delhi: National Commission for Women.

NCERT. (2005). National Curriculum Framework-2005. New Delhi: National Council of Educational Research and Training (NCERT). Retrieved from https://ncert.nic.in/pdf/nc-framework/nf2005english.pdf

NCERT. (2006). Gender Issues In education. New Delhi: National Council of Educational Research and Training.

NUEPA. (2012). SECONDARY EDUCATION IN INDIA(U-DISE, State Report Card: 2010-11). New

Delhi: NUEPA. Retrieved from http://udise.in/Downloads/Publications/SEMIS/201011/State\%20Report\%20Cards\%202010-11.pdf

NUEPA. (2013). SECONDARY EDUCATION IN INDIA(U-DISE, State Report Card: 2012-13). New

Delhi: NUEPA. Retrieved from

http://udise.in/Downloads/Publications/Documents/Secondary_State_Report_Card_2012-13.pdf

NUEPA. (2014). SECONDARY EDUCATION IN INDIA(U-DISE, State Report Card: 2013-14). New

Delhi: NUEPA. Retrieved from http://udise.in/Downloads/SEMIS-STRC-2013-14/SEMIS-

State_Report_Cards_2013-14.pdf

NUEPA. (2015). SECONDARY EDUCATION IN INDIA(U-DISE, State Report Card: 2014-15). New

Delhi: NUEPA. Retrieved from http://udise.in/Downloads/SEMIS-STRC-2014-15/SEMIS-

State_Report_Cards_2014-15.pdf

NUEPA. (2016). SECONDARY EDUCATION IN INDIA(U-DISE, State Report Card: 2015-16). New

Delhi: NUEPA. Retrieved from http://udise.in/Downloads/SEMIS-STRC-2015-16/SEMIS-

State_Report_Cards_2015-16.pdf

NUEPA. (2017). SECONDARY EDUCATION IN INDIA(U-DISE, State Report Card: 2016-17). New

Delhi: NUEPA. Retrieved from http://udise.in/Downloads/SEMIS-STRC-2016-17/SEMIS-

State_Report_Cards_2016-17.pdf

OECD. (2012). Equity and Quality in Education: : Supporting Disadvantaged Students and Schools.

OECD Publishing. Retrieved from https://www.oecd.org/education/school/50293148.pdf

Pratichi Institute. (2013). Secondary Education in West Bengal Prospects and Challenges. Kolkata: UNICEF. 
Ramachandran, V. (2004). Gender equality in education in India. UNESCO: Education for All Global Monitoring Report 2003/4.

Rustagi, P. (2004). Significance of Gender-related Development Indicators: An Analysis of Indian States. Indian Journal of Gender Studies, 11(3), 291-343. Retrieved from http://www.dise.in/Downloads/Use\%20of\%20Dise\%20Data/Preet\%20Rustagi.pdf

T. Haque and D. Narasimha Reddy. ((2019)). INDIA- Social Development Report 2018: Rising Inequalities in India. Council for SocialDevelopment: Oxford University Press.

UNESCO. (2019). Global Education Monitoring Report - Gender Report: Building bridges for gender equality. Paris: UNESCO. 